\title{
Tendencias genéticas y fenotípicas para producción de leche de ganado Holstein en dos modalidades de control de producción
}

\section{Estimation of milk production genetic and phenotypic trends in Holstein cattle in Mexico}

\author{
Hugo O. Toledo Alvaradoa, Felipe de Jesús Ruiz Lópezb, Carlos G. Vázquez Peláeza, \\ J osé M. Berruecos Villalobosa, Mauricio A. Elzoc
}

\begin{abstract}
RESUMEN
Se utilizaron registros de producción de leche ajustada a 305 días, equivalente edad adulta y dos ordeñas de la primera lactancia, del Programa Nacional de Mejoramiento Genético en México PNMG $(\mathbf{n}=163,885)$, que incluye a la Asociación Holstein de México (AHM) $(n=43,668)$ y al Banco Nacional de Información Lechera (BNIL) $(n=120,217)$. El objetivo del estudio fue el análisis de las tendencias genéticas de poblaciones Holstein en México. Se utilizó el método del Mejor Predictor Lineal Insesgado para predecir los valores genéticos (VG) de los animales con un modelo animal usando el programa ASREML, el modelo incluyó el grupo hato-año-estación de parto como efecto fijo, y animal y residuo como aleatorios. Se estimaron los promedios de los VG de los sementales ponderados por el número de hijas y no ponderados del PNMG, AHM y BNIL. Así como los promedios ponderados de los VG de los sementales del PNMG de acuerdo a su país de origen (EUA, Canadá, México y Otros). También se estimaron los promedios de VG y valores fenotípicos (VF) para las vacas en producción. Los VG y VF promedios de las vacas del PNMG, AHM y BNIL aumentaron entre el 2007 y el 2011. Ganaderos de la AHM escogieron sementales con mayores VG que los del BNIL. Sin embargo, ganaderos del BNIL utilizaron sementales con altos VG más frecuentemente. Los sementales extranjeros tuvieron VG superiores a los nacionales y fueron más utilizados por los ganaderos.
\end{abstract}

PALABRAS ClAVE: Tendencias genéticas, Tendencias fenotípicas, Holstein, Producción leche.

\begin{abstract}
Records of milk production adjusted to $305 \mathrm{~d}$, adult equivalent of the first lactation and two milking were used. Those come from the National Breeding in Mexico PNMG $(n=163.885)$, which includes records of the Holstein Association of Mexico (AHM) $(n=43.668)$ and National Bank of Dairy Information (BNIL) $(n=120.217)$. Best Linear Unbiased Predictor method was used to predict breeding values (VG) of animals. ASREML software was used with an animal model that included herd-year group-season as fixed effect and animal and residue as random effects. Averages of VG per sire were estimated weighted by the number of daughters and unweighted for PNMG, AHM and BNIL. Also, we estimated the weighted average of the sires VG of the PNMG according to their country of origin (USA, Canada, Other, Mexico). We also estimated the average of VG and phenotypic values (VF) for dairy cows. The average of VF and VG for cows PNMG, AHM and BNIL increased between 2007 and 2011 . Breeders of the AHM chose sires with greater VG than the BNIL. However, breeders of BNIL used sires with high VG used more frequently. The VG for foreign sires were higher than national sires and were more commonly used by farmers.
\end{abstract}

KEY WORDS: Genetic trends, Phenotypic trends, Holstein, Production.

Los sistemas especializados producen más del $50 \%$ de la leche en México, siendo la raza
Over $50 \%$ of milk in Mexico is produced in specialized systems, most of which use the

Recibido el 29 de noviembre de 2012. Aceptado el 10 de junio de 2013.

a Departamento de Genética y Bioestadística, Facultad de Medicina Veterinaria y Zootecnia, Universidad Nacional Autónoma de México. Av. Universidad 3000, Copilco el Alto 04510. México DF. h.toledo.a@gmail.com. Correspondencia al primer autor.

b Centro Nacional de Investigación en Fisiología y Mejoramiento Animal. INIFAP-SAGARPA. Ajuchitlán Querétaro. México.

c Department of Animal Sciences, University of Florida. Gainesville, FL, USA. 
Holstein la más usada(1). Las evaluaciones así como los estudios genéticos que se han realizado para Holstein en México han sido escasos y solamente tomaron en cuenta a los animales registrados ante la Asociación Holstein de México (AHM) (2). Por lo tanto, se desconoce el progreso genético que han tenido hatos Holstein fuera de la asociación, pero que contribuyen en gran medida a la producción nacional, como es el caso del Banco Nacional de Información Lechera (BNIL) que actualmente se encuentra dentro del Programa Nacional de Mejoramiento Genético (PNMG) que incluye a la AHM y al BNIL. Por lo que es importante evaluar los cambios en los valores genéticos de los padres de las vacas Holstein y su utilización en la población a través del tiempo. La base de datos de leche del PNMG presenta una excelente oportunidad para evaluar tendencias genéticas y fenotípicas de vacas y de toros durante los últimos cinco años(3). Por ello, los objetivos de este trabajo fueron: a) analizar las tendencias genéticas y fenotípicas para la producción de leche en la primera lactancia ajustada a 305 días del ganado registrado en el PNMG que incluyen datos de la AHM y del BNI L. b) analizar las tendencias genéticas ponderadas y no ponderadas de los sementales de la AHM, del $B N I L$, y del PNMG (AHM y BNIL juntas), con el fin de determinar la relación entre sus valores genéticos predichos y su utilización como padres en cada población y c) analizar las tendencias genéticas de los sementales ponderadas por el número de hijas en el PNMG de acuerdo a su país de origen.

\section{Animales y datos}

Se utilizaron los registros del PNMG en México, que incluye los registros de la AHM y del BNI L, el cual consiste en datos obtenidos por ganaderos no registrados ante la asociación Holstein. En total se usaron 163,885 registros del PNMG de vacas en su primera lactancia, hijas de 1,694 toros. Para la AHM se contabilizó un total de 43,668 vacas hijas de 767 toros, mientras que el BNI L tuvo 120,217 vacas hijas de 1,528 toros. Los años usados en el presente
Holstein breed(1). The very few genetic studies and evaluations done on the Holstein breed in Mexico have only included animals registered in the Holstein Association of Mexico (Asociación Holstein de México - AHM)(2). Little is known of the genetic progress of Holstein herds outside the AHM, although they contribute substantially to national milk production. The National Genetic Improvement Program (Programa Nacional de Mejoramiento Genético - PNMG) encompasses the AHM as well as the National Dairy Data Bank (Banco Nacional de Información Lechera - BNIL). A thorough understanding of the genetic progress of the Holstein breed in Mexico requires evaluation of changes in genetic values in the fathers of Holstein cows, and how these have been applied over time. The PNMG dairy herd database presents an excellent opportunity to evaluate genetic and phenotypic tendencies in Holstein cows and bulls over a five-year period(3). Using this database, the present study objectives were to a) Analyze genetic and phenotypic tendencies in milk production in the first lactation adjusted to $305 \mathrm{~d}$ in cattle recorded in the PNMG; b) Analyze weighted and unweighted tendencies for sires in the AHM, BNIL and PNMG (i.e. AHM+BNIL) populations to identify their predicted genetic values and their use as fathers in each population; and c) Analyze weighted sire genetic tendencies by number of daughters in the PNMG by country of origin.

\section{Animals and data}

Data were gleaned from PNMG records in Mexico, including AHM records, and BNI L records (i.e. data from producers not registered with the AHM). Overall, 163,885 records from the PNMG were used for first lactation cows, which were the daughters of 1,694 bulls. Of this total, AHM records represented 43,668 cows (daughters of 767 bulls), and BNIL records represented 120,217 cows (daughters of 1,528 bulls). The BNIL data covered 2007 to 2011, and therefore only AHM data from these years was used. 
trabajo fueron de 2007 a 2011, ya que en este periodo es donde se encuentra información del BNIL.

\section{Edición de la información}

Se utilizaron registros de primera lactancia con información de producción de leche ajustada a 305 días, equivalente edad adulta y dos ordeñas. Se eliminaron registros de vacas con menos de 18 meses de edad al primer parto, animales con razas diferentes a la Holstein o con progenitores de raza diferente a Holstein, registros con producciones menores a $1,500 \mathrm{~kg}$ de leche (por considerarse que no se registró una lactancia completa), y registros de animales con menos de 90 días en lactación para asegurar al menos tres pesajes. El pedigrí final contó con 350,860 animales.

Las bases editadas de datos y el archivo de pedigrí se generaron con un programa en lenguaje C\#4 y el Sistema de análisis estadístico (SAS) ${ }^{(5)}$.

\section{Clima, nutrición y manejo}

Los datos provienen de 22 estados de la República Mexicana: Aguascalientes, Baja California, Chiapas, Chihuahua, Coahuila, Durango, Estado de México, Guanajuato, Guerrero, Hidalgo, Jalisco, Michoacán, Morelos, Nayarit, Oaxaca, Puebla, Querétaro, San Luis Potosí, Sinaloa, Tlaxcala, Veracruz y Zacatecas(6). Hubo cinco tipos de climas en estos estados. Dos estados tuvieron clima seco desértico, 6 clima seco estepario, 4 cálido húmedo, 2 cálido semi-humedo y 8 templado semi-humedo. El clima seco desértico presenta temperaturas entre 0 y $40^{\circ} \mathrm{C}$, precipitaciones pluviales (PP) inferiores a los $400 \mathrm{~mm}$ por año en el verano. El clima seco estepario presenta temperaturas entre 8 y $28^{\circ} \mathrm{C}$, y PP $<750 \mathrm{~mm}$ en verano. El clima cálido húmedo y el semihumedo tienen temperaturas entre 18 a $21^{\circ} \mathrm{C}$, con PP de 750 a 1500 mm (en el semi-humedo sólo se presentan en verano). El clima templado semi-humedo presenta temperaturas de 12 a $18{ }^{\circ} \mathrm{C}$ y PP de 600 a $1,500 \mathrm{~mm}$ en verano(7).

\section{Data editing}

First lactation data were used and milk production data adjusted to $305 \mathrm{~d}$, equivalent adult age and two milkings. Records were eliminated for cows less than $18 \mathrm{mo}$ of age at first parturition, non-Holstein cows, cows with non-Holstein progenitors, records with less than $1,500 \mathrm{~kg}$ milk production (considered an incomplete lactation), and cows with less than $90 \mathrm{~d}$ lactation (to ensure at least three weighings). The final pedigree consisted of 350,860 cows. The databases and pedigree file were generated with a program in the $\mathrm{C \#}$ language(4) and the SAS program(5).

\section{Climate, nutrition and management}

The analyzed data came from 22 States in Mexico: Aguascalientes, Baja California, Chiapas, Chihuahua, Coahuila, Durango, Estado de México, Guanajuato, Guerrero, Hidalgo, Jalisco, Michoacán, Morelos, Nayarit, Oaxaca, Puebla, Querétaro, San Luis Potosí, Sinaloa, Tlaxcala, Veracruz and Zacatecas(6). These states are located in five different climate types. Two have a dry desert climate consisting of temperatures from 0 to $40^{\circ} \mathrm{C}$, and annual rainfall $<400 \mathrm{~mm}$, primarily during the summer rainy season. Six have a dry steppe climate consisting of temperatures from 8 to $28{ }^{\circ} \mathrm{C}$, and annual rainfall $<750 \mathrm{~mm}$, primarily in the summer. Four states have a warm humid climate and two a warm sub-humid climate consisting of temperatures from 18 to $21{ }^{\circ} \mathrm{C}$ and annual rainfall from 750 to $1500 \mathrm{~mm}$ (only in summer in subhumid climate). And eight have a temperate sub-humid climate with temperatures from 12 to $18{ }^{\circ} \mathrm{C}$ and annual rainfall from 600 to $1500 \mathrm{~mm}$, primarily in summer $(7)$.

A contemporary group effect was created by combining the factors of herd, year and year of birth. Based on general seasonal rainfall patterns, two birth seasons were defined: 1 ) December to May (dry season); and 2) June to November (rainy season).

Feed raw materials and management systems varied widely among producers. Generally, they 
Se creó un efecto de grupo contemporáneo combinando los factores hato-año-estación de parto. Se definieron dos estaciones de parto: estación 1 de diciembre a mayo y estación 2 de junio a noviembre de acuerdo a la época de lluvias.

La alimentación y manejo fueron muy variados. La alimentación se basó en corte y acarreo, uso de silo, heno y concentrados con suplementación de minerales, además se aprovecharon productos locales de residuos de cultivos y sub-productos industriales. Los principales forrajes usados fueron maíz (Zea mays), avena (Avena sativa), alfalfa (Medicago sativa), sorgo forrajero (Sorghum vulgare), raygrass (Lolium spp.), trébol blanco (Trifolium repens), pasto Kikuyu (Pennisetum clandestinum) y pastos nativos (8).

\section{Estimación de valores genéticos}

Se predijeron los valores genéticos de los animales a través del método del Mejor Predictor Lineal Insesgado utilizando varianzas genéticas y ambientales para producción de leche al primer parto estimadas por Toledo et al(3). Los cómputos se realizaron con el programa $\operatorname{ASREML}(9,10)$. El modelo incluyó grupo contemporáneo (hato-añoestación de parto) como efecto fijo, y animal y residuo como efectos aleatorios. En forma matricial, el modelo mixto fue(11):

$$
\begin{gathered}
y=X b+Z u+e \\
{\left[\begin{array}{l}
y \\
u \\
e
\end{array}\right] \sim \operatorname{MVN}\left\{\left[\begin{array}{c}
X \beta \\
0 \\
0
\end{array}\right],\left[\begin{array}{ccc}
Z G Z^{\prime}+R & G Z^{\prime} & R \\
G Z^{\prime} & G & 0 \\
R & 0 & R
\end{array}\right]\right\}}
\end{gathered}
$$

Donde: $y=$ vector de observaciones de producción de leche estandarizada de la primera lactancia de las vacas; $b=$ vector de hato-añoestación; $u=$ vector de los efectos aleatorios genéticos aditivos animales; $e=$ vector de efectos aleatorios residuales; $X=$ matriz de incidencia que relaciona los registros con los elementos de b; $\mathbf{Z}=$ matriz de incidencia que relaciona los registros con los elementos de $\mathrm{u}$; $\mathrm{G}=A \sigma_{a}^{2}$, donde $\mathrm{A}=$ es la matriz de relaciones involved harvesting, transport and silage of raw material, hay and concentrates with mineral supplementation. Local crop residues and industrial by-products were also used in some cases. Some native grasses were used, but seven main forage species predominated: corn (Zea mays); oats (Avena sativa); alfalfa (Medicago sativa); forage sorghum (Sorghum vulgare); raygrass (Lolium spp.); white clover (Trifolium repens); and Kikuyu grass (Pennisetum clandestinum).

Genetic value estimation

Cow genetic values (GV) were predicted using the Best Unbiased Linear Predictor method, employing first parturition milk production genetic and environmental variances estimated by Toledo et al(3). Calculations were done with the ASREML program $(9,10)$. The model included contemporary group (i.e. herd-year-birth season) as a fixed effect, and animal and residual as random effects. As a matrix, the mixed model was(11):

$$
\begin{gathered}
y=X b+Z u+e \\
{\left[\begin{array}{l}
y \\
u \\
e
\end{array}\right] \sim M V N\left\{\left[\begin{array}{c}
X \beta \\
0 \\
0
\end{array}\right],\left[\begin{array}{ccc}
Z G Z^{\prime}+R & G Z^{\prime} & R \\
G Z^{\prime} & G & 0 \\
R & 0 & R
\end{array}\right]\right\}}
\end{gathered}
$$

where $\mathrm{y}=$ standardized first lactation milk production observation vector; $b=$ herd-yearseason vector; $\mathrm{u}=$ animal genetic, additive random effects vector; $X=$ incidence matrix relating records to the elements of $b ; z=$ incidence matrix relating records to the elements of $\mathrm{u} ; \mathrm{G}=A \sigma_{a}^{2}$, where $\mathrm{A}=$ additive relations matrix and $\sigma_{a}^{2}=$ additive variance; and $\mathrm{R}=I \sigma_{\theta}^{2}$, where $\mathrm{I}=$ identity matrix and $\sigma_{\theta}^{2}=$ residual variance. Variances were estimated in a previous study(5).

Estimation of average genetic values

Averages for cow GV were estimated by birth year from 2007 to 2011. Weighted and unweighted averages were estimated for sire $\mathrm{GV}$; these were for the fathers of daughters 
aditivas y $\sigma_{a}^{2}=$ varianza aditiva; y $\mathrm{R}=I \sigma_{\theta}^{2}$, donde I es una matriz de identidad y $\sigma_{\theta}^{2}=$ varianza residual. Las varianzas fueron estimadas en un estudio previo (Toledo et al(5) $2 x x x$ ).

Estimación de promedios de valores genéticos Se estimaron promedios de valores genéticos (VG) de vacas por año de parto desde el 2007 al 2011. Para los sementales se estimaron promedios ponderados y no ponderados de VG, estos promedios son de padres de hembras paridas en los años de estudio. Por lo que el valor genético del semental es de un animal que se usó al menos tres años antes del primer parto de su hija. Los VG ponderados se calcularon utilizando la siguiente expresión de una media ponderada:

$$
\bar{X}_{i j}=\frac{\sum_{j=1}^{n} V G_{j} N_{i j}}{\sum_{i=1}^{n} N_{i j}}
$$

Donde $\bar{X}_{i j}=$ promedio genético ponderado del semental $\mathrm{j}$ en el año $\mathrm{i}, V_{\mathrm{j}}=$ es el $V G$ del j-ésimo semental y $\mathrm{N}_{\mathrm{ij}}=$ es número de hijas del toro j en el año i. En el caso de las madres de las vacas no se calcularon promedios (ponderados o no ponderados) debido al bajo porcentaje de madres de vacas identificadas en el BNIL (1 \%).

Los promedios de VG ponderados se estimaron de acuerdo al país de procedencia del semental para el PNMG, clasificándolos en cuatro categorías: Canadá, Estados Unidos de América (EUA), México, y Otros (Alemania, Australia, Austria, España, Francia, Gran Bretaña, Holanda, Italia, Nueva Zelandia, Republica Checa, y Suecia).

Estimación de promedios de valores fenotípicos El valor fenotípico (VF) de las vacas se estimó como:

$$
\hat{p}_{i}=\hat{u}_{i}+\hat{e}_{\bar{i}}
$$

Donde $\hat{p}_{i}=$ es el valor del registro fenotípico de la primera lactancia de la vaca i, $\hat{u}_{i}=$ es el born within the study period. Therefore, a sire GV is for a bull used at least three years before his daughter's parturition. The weighted GV were calculated using the weighted mean formula:

$$
\bar{X}_{i j}=\frac{\sum_{j=1}^{n} G V_{j} N_{i j}}{\sum_{i=1}^{n} N_{i j}}
$$

where $\bar{X}_{i j}=$ weighted genetic average of sire $\mathrm{j}$ in year $\mathrm{i} ; \mathrm{GV}_{\mathrm{j}}=$ the $\mathrm{GV}$ of the $\mathrm{j}$-th sire; and $\mathrm{N}_{\mathrm{ij}}=$ number of daughters for bull $\mathrm{j}$ in year $\mathrm{i}$. Averages (weighted or unweighted) were not calculated for the cows' mothers due to the low percentage ( $1 \%)$ of mothers identified in the BNIL.

Averages for the weighted GV were estimated by sire country of origin in the PNMG, and were grouped into four categories: Canada; the United States of America (USA); Mexico; and Others (i.e. Germany, Australia, Austria, Spain, France, Great Britain, the Netherlands, Italy, New Zealand, the Czech Republic and Sweden).

Estimation of phenotypic value averages Cow phenotypic values $(\mathrm{PhV})$ were estimated as

$$
\hat{p}_{i}=\hat{u}_{i}+\hat{e}_{i}
$$

where $\hat{p}_{i}=$ is the first lactation phenotypic record for cow $\mathrm{i} ; \hat{u}_{i}=$ is the additive genetic value of cow I; and $\hat{e}_{i}=$ is the first lactation residual value for cow i. Error was estimated as

$$
\hat{e}_{i}=y_{i}-\widehat{g c}_{i}
$$

where $\hat{e}_{i}=$ the first lactation residual value for cow $\mathrm{i} ; \mathrm{y}_{\mathrm{i}}=$ production standardized to 305 days and first lactation adult age for cow i; and $\widehat{g c}_{i}=$ estimation of contemporary group i. Annual averages for PhV were estimated using these values.

\section{Genetic tendencies}

Genetic value averages were generated for first parturition milk production in the PNMG, AHM, and BNIL populations (Table 1, Figure 1). Data 
valor genético aditivo de la vaca i, y $\hat{e}_{i}=$ es el valor del residuo de la primera lactancia de la vaca i. El error se estimó como:

$$
\hat{e}_{i}=y_{i}-\widehat{g c}_{i}
$$

Donde $\hat{e}_{i}=$ es el valor del residuo de la primera lactancia de la vaca $\mathrm{i} ; \mathrm{y}_{\mathrm{i}}=$ es la producción estandarizada a 305 días y a edad adulta de la primera lactancia de la vaca i; y $\widehat{g c} c_{i}=$ es la estimación del grupo contemporáneo i. Con estos valores se estimaron los promedios anuales de los valores fenotípicos.

Descripción de datos

En el Cuadro 1 se presentan los estadísticos descriptivos generales de los valores genéticos aditivos y fenotípicos de las vacas, y de los VG for 2007 GV were not graphed because the sample contained limited data and was therefore not representative of the population. This was the first year the BNIL participated in the PNMG, and records were for selected animals within production units rather than all animals. Beginning in 2008, BNIL production behaved similarly to that in the AHM and PNMG data. Milk production GV increased from 2008 to 2011, suggesting that producers gradually increased their use of better genetic quality cows and bulls in this time period. Genetic values were higher in the AHM data than in the BNIL data, except in 2011 when they had similar averages. Average values in the PNMG data were similar to those in the BNIL because BNIL data represented a larger proportion of the PNMG database than AHM data.

Cuadro 1. Estadísticos descriptivos de los valores genéticos (GV) y valores fenotípicos (PhV) para el Programa Nacional de Mejoramiento Genético (PNMG); la Asociación Holstein de México (AHM) y el Banco Nacional de Información Lechera (BNIL)

Table 1. Genetic (GV) and phenotypic value (PhV) statistics based on data from the National Genetic Improvement Program (PNMG), the Holstein Association of Mexico (AHM) and the National Dairy Data Bank (BNIL)

\begin{tabular}{lcccccc}
\hline & N & Mean & SD & Min & Max & SE \\
\hline Sires, weighted GV & & & & & & \\
AHM & 21532 & 553.0 & 705.2 & -3546 & 2640 & 4.81 \\
BNIL & 57732 & 750.8 & 596.2 & -1722 & 2949 & 2.48 \\
PNMG & 79264 & 697.1 & 633.8 & -3546 & 2949 & 2.25 \\
Sires, unweighted GV & & & & & & \\
AHM & 2006 & 401.9 & 678.2 & -3546 & 2640 & 15.1 \\
BNIL & 2991 & 396.5 & 601.4 & -1722 & 2949 & 11.0 \\
PNMG & 4997 & 398.7 & 633.3 & -3546 & 2949 & 8.96 \\
Cows, GV & & & & & & \\
AHM & 43668 & 187.2 & 613.6 & -2846 & 2695 & 2.94 \\
BNIL & 120217 & 189.3 & 543.1 & -2344 & 3357 & 1.57 \\
PNMG & 163885 & 188.8 & 562.8 & -2846 & 3357 & 1.39 \\
Cows, PhV & & & & & & \\
AHM & 43668 & 374.8 & 2671.9 & -10922 & 12025 & 12.7 \\
BNIL & 120217 & 378.7 & 2403.7 & -10572 & 14219 & 6.93 \\
PNMG & 163885 & 377.6 & 2478.0 & -10922 & 14219 & 6.12 \\
\hline
\end{tabular}

$\mathrm{N}=$ number of observations; $\mathrm{SD}=$ Standard Deviation; Min= Minimum; Max= Maximum; SE= Standard error. 
Figura 1. Tendencias genéticas de producción de leche a 305 días de las vacas por año de parto, para el Programa Nacional de Mejoramiento Genético (PNMG); la Asociación Holstein de México (AHM) y el Banco Nacional de Información Lechera (BNIL)

Figure 1. Cow 305-d milk production genetic tendencies by year of birth based on data from the National Genetic Improvement Program (PNMG), the Holstein Association of Mexico (AHM) and the National Dairy Data Bank (BNIL)

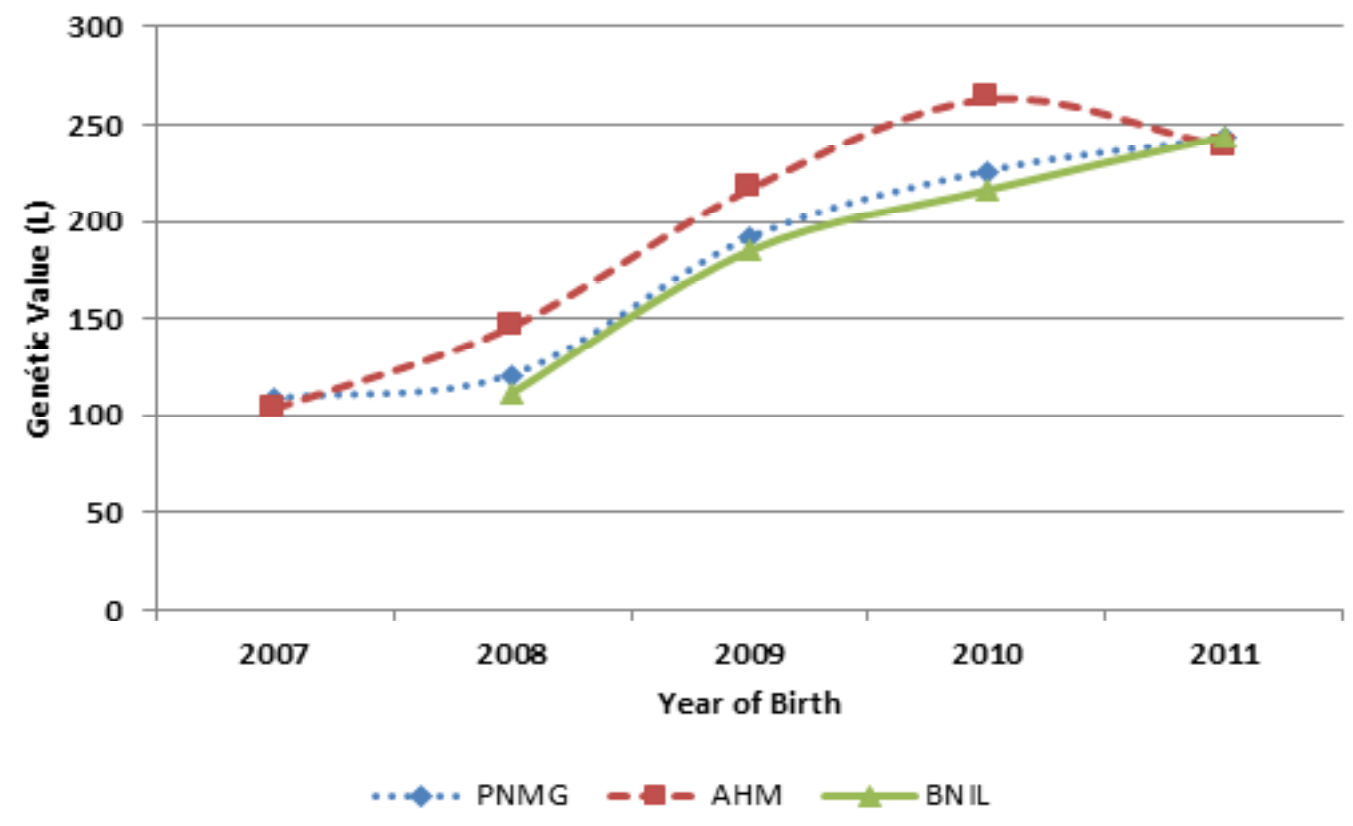

de los sementales para producción de leche en la primera lactancia en la población completa (PNMG) y en las dos subpoblaciones (AHM y BNIL).

Tendencias genéticas

Los promedios de los VG de producción de leche a primer parto de las vacas en las poblaciones PNMG, AHM, y BNIL se presentan en la Figura 1. En el año 2007 no se graficaron los VG del BNIL, debido a que en ese año no se tuvo un muestreo representativo de esta población al ser muy pocos datos, ya que era el primer año de participación del BNIL en el PNMG, los registros eran de animales seleccionados dentro de las explotaciones y no de todos los animales. A partir del año 2008, se observó un comportamiento similar al de la AHM y del PNMG. Los valores genéticos de las
Weighted and unweight 305-d annual milk production GV were generated for AHM cows and sires (Figure 2). Unweighted sire GV increased from 2007 to 2011, suggesting that AHM producers gradually increased their use of sires with better average genetic quality. Weighted sire GV increased to 2010 with only a slight increase in 2011, implying that producers used better quality sires more frequently during these years. Preferential use of high GV sires from 2007 to 2011 resulted in the same patterns in weighted averages (although with lower values) for the cows as for their fathers.

Weighted and unweight 305-d annual milk production GV were also generated for BNIL cows and sires (Figure 3). Values for 2007 are not shown due to lack of representativity (see above). Unweighted average sire GV exhibited a slight decrease from 2008 to 2011, although 
vacas para producción de leche aumentaron entre 2008 y el 2011, lo cual implica que los ganaderos incrementaron gradualmente la utilización de vacas y toros con mejor calidad genética en sus hatos durante estos años. La AHM mostró VG mayores al BNIL, excepto en el año 2011 donde tuvieron valores promedio de VG similares. Los promedios de VG para el PNMG fueron similares a los del BNIL debido al mayor número de vacas del BNIL que forman parte del PNMG con respecto a las de la AHM.

Las tendencias de los VG para producción de leche a 305 días por año para las vacas y los sementales (medias ponderadas y no ponderadas) en la AHM se muestran en la Figura 2. Los VG no ponderados de los toros aumentaron entre el año 2007 y el 2011, sugiriendo que los ganaderos de la AHM utilizaron gradualmente toros de mejor calidad genética en promedio. Por otra parte, los VG ponderados de los sementales aumentaron hasta el año unweighted average GV were very similar from year to year. This suggests that even though BNIL producers acquired genetic material from sires of progressively lower quality in this period, they used superior quality sires more frequently. This sire use pattern led to a quasi-linear increase in average GV among daughters during the same period.

For the PNMG, the weighted and unweight 305-d annual milk production GV showed unweighted sire GV to increase from 2007 to 2011 (Figure 4). Unweighted GV increased up to 2010 but decreased slightly in 2011, following a quadratic trajectory. The cows exhibited an almost linear increase during this period. Average GV change patterns in the PNMG, particularly the cow and weighted sire averages, were nearer those of the AHM than those of the BNIL.

Unweighted average sire GV by birth year showed average sire GV to be higher in the

Figura 2. Tendencias genéticas de producción de leche a 305 días por año de parto, para las vacas y año de parto de las hijas de los sementales (medias ponderadas y no ponderadas) en la Asociación Holstein de México

Figure 2. Cow 305-d milk production genetic tendencies by daughter year of birth for sires (weighted and unweighted means) registered in the Holstein Association of Mexico

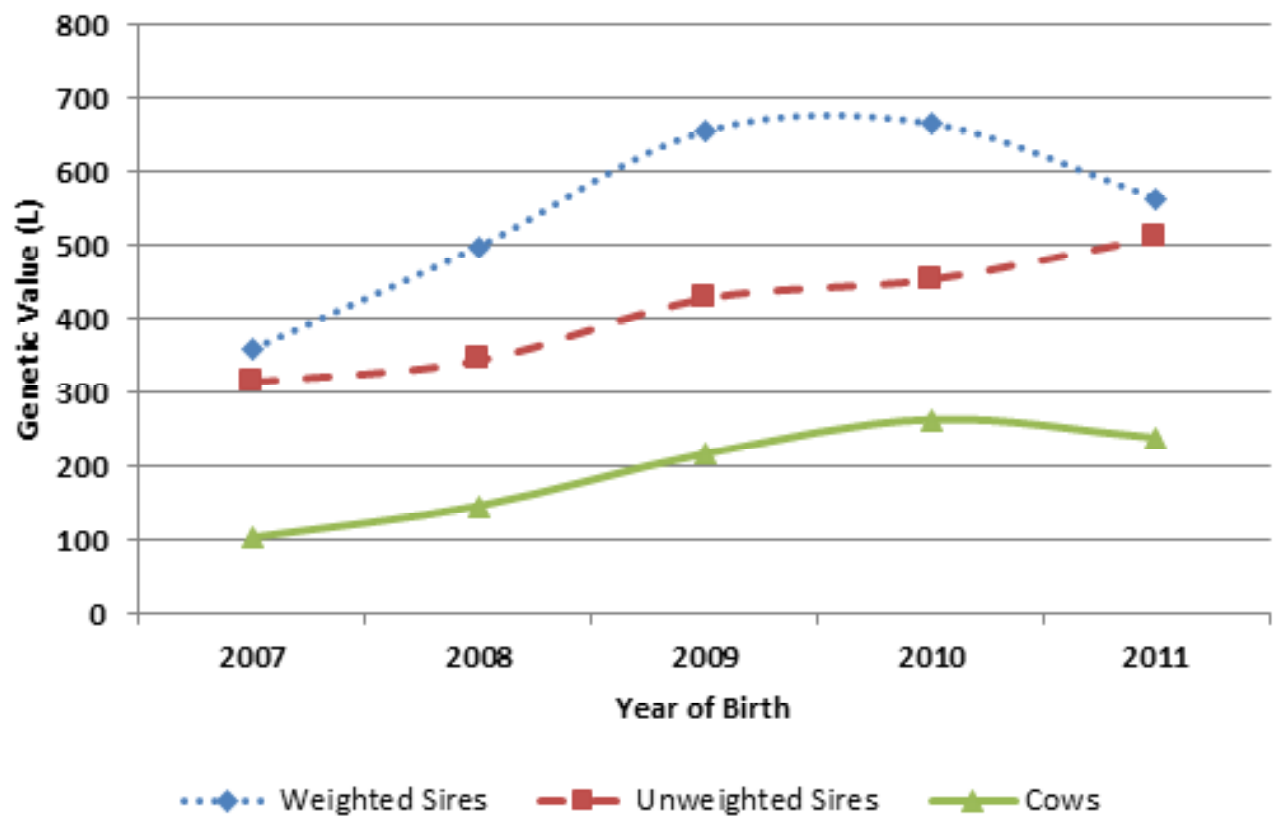


Figura 3. Tendencias genéticas de producción de leche a 305 días por año de parto, para las vacas y año de parto de las hijas de los sementales (medias ponderadas y no ponderadas) en el Banco Nacional de Información Lechera

Figure 3. Cow 305-d milk production genetic tendencies by daughter year of birth for sires (weighted and unweighted means) registered in the National Dairy Data Bank

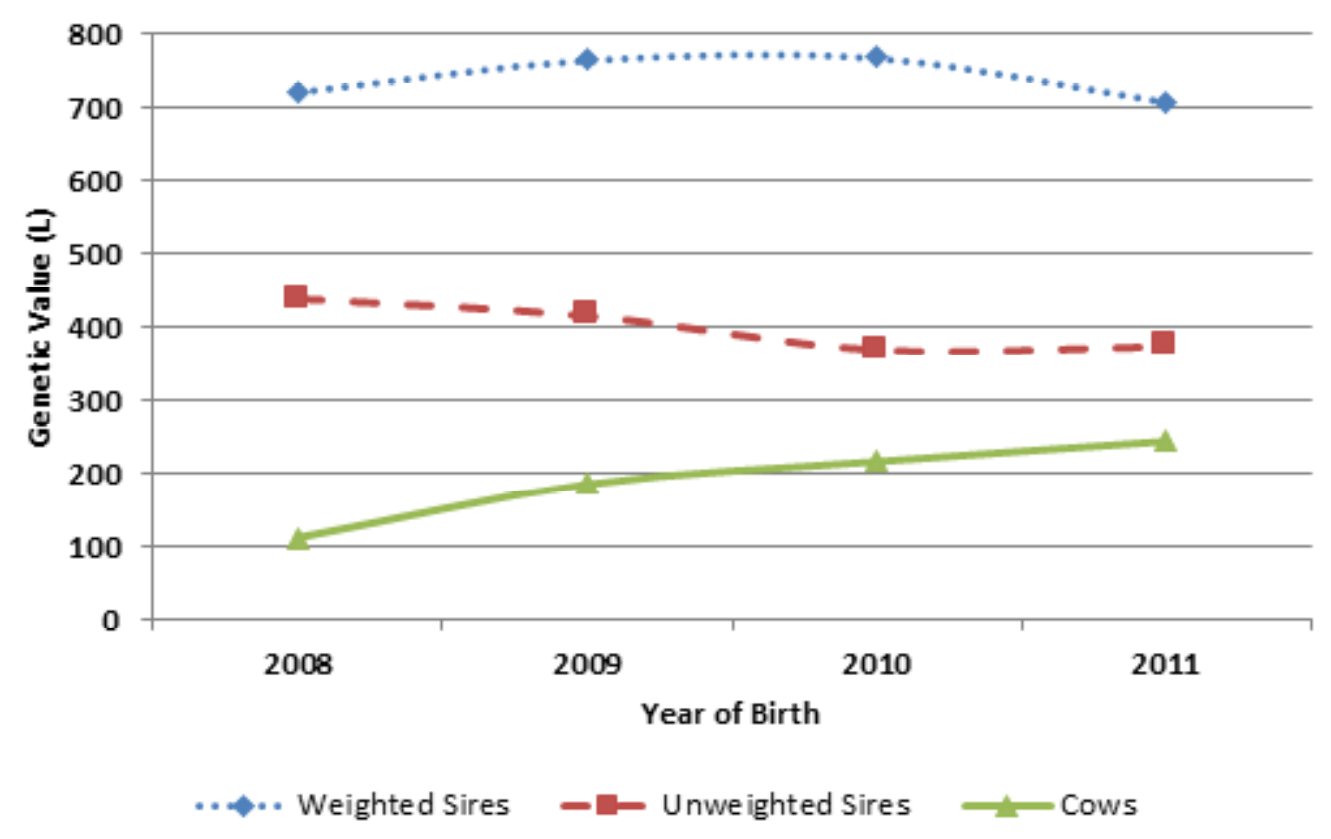

2010 y solamente hubo un leve decremento en el 2011. Esto implica que los ganaderos de la AHM utilizaron aquellos toros de mejor calidad genética más frecuentemente durante estos años. Debido a este uso preferencial de toros desde el 2007 al 2011 es que los promedios de VG de las vacas, aunque inferiores, tuvieron esencialmente el mismo patrón a los promedios ponderados de sus padres.

Los promedios anuales de los VG de producción de leche a los 305 días de las vacas y de los sementales (medias ponderadas y no ponderadas) del BNIL se pueden ver en la Figura 3. Los valores de VG de las vacas y de los toros del año 2007 no se mostraron debido a que la muestra de animales del BNIL no fue representativa de esta población. Se observó un ligero decremento de los VG no ponderados de los sementales desde el año 2008 al 2011; sin embargo, los promedios de VG ponderados
AHM data than in the BNIL and PNMG data, except in 2007 (non-representative sample in BNIL). (Figure 5) Cow GV exhibited similar behavior. In contrast, weighted average sire GV were higher in the BNIL data than in the AHM and PNMG data (Figure 6). This implies that even though the BNIL producers chose bulls of variable GV they most frequently chose those with the highest GV values. The AHM producers chose bulls with more homogeneously high GV, resulting in higher average GV in both sires and daughters.

The genetic tendencies of the unweighted averages for sires and cow milk production coincide with other studies which report increased average GV for sires and cow milk production in herds in Mexico(2,12-15). This is probably an effect of migration of genetic material (mainly from the USA) together with parent selection as part of genetic improvement programs in Mexico. 
Figura 4. Tendencias genéticas de producción de leche a 305 días por año de parto, para las vacas y año de parto de las hijas de los sementales (medias ponderadas y no ponderadas) para el Programa Nacional de Mejoramiento Genético

Figure 4. Cow 305-d milk production genetic tendencies by daughter year of birth for sires (weighted and unweighted means) registered in the National Genetic Improvement Program

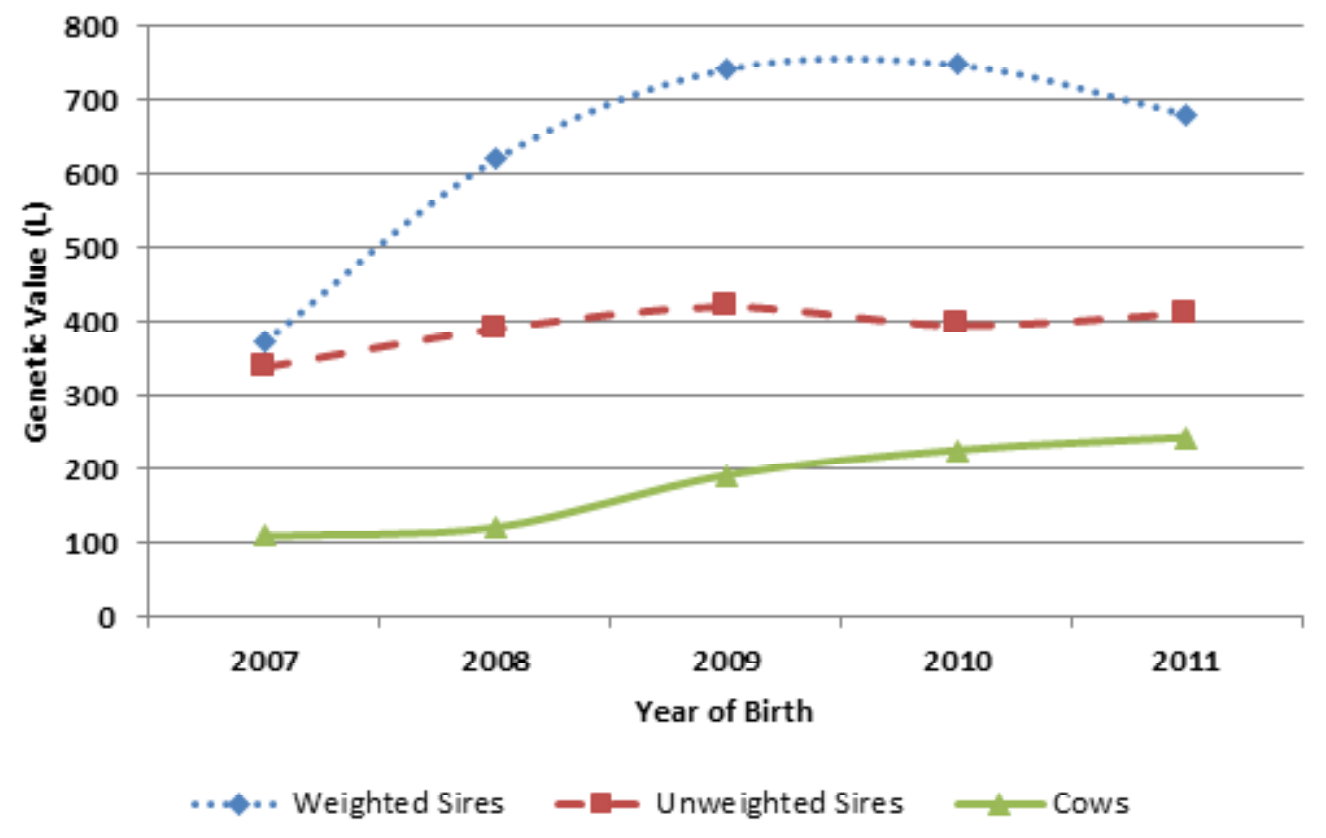

de los sementales fueron muy similares a través de estos años. Esto sugiere que aunque los ganaderos del BNIL adquirieron material genético de sementales de calidad genética decreciente durante estos años, ellos utilizaron toros de calidad genética superior con mayor frecuencia. Este patrón de utilización de sementales también permitió un aumento quasilineal del promedio de VG de sus hijas entre el año 2008 y el 2011.

Los promedios anuales de VG de producción de leche a 305 días de vacas y sementales (medias ponderadas y no ponderadas) para el PNMG están en la Figura 4. Los VG no ponderados de los sementales aumentaron entre el 2007 y el 2011. Por otra parte, los VG ponderados de los sementales aumentaron hasta el 2010 y disminuyeron levemente en el 2011, siguiendo una trayectoria cuadrática. Finalmente las vacas tuvieron un incremento casi lineal durante este tiempo. Estos patrones
Weighted average PNMG sire GV for 305-d milk production by year of birth broken down into country of origin categories reflects to what degree sires of different origins were used (Figure 7). Average weighted GV were highest in the USA category, with values that increased up to 2010 and decreased slightly in 2011. This is similar to the pattern in weighted average GV observed for the PNMG, which included GV for sires from all the countries (Figure 6). This could be expected since sires from the USA represented $70 \%$ of those in the PNMG. The Others category had weighted average GV lower than the USA category, but higher than the Canada and Mexico categories; this, despite the countries in the Others category representing only $13 \%$ of the total. Weighted averages in this category increased up to 2009 and decreased in 2010 and 2011, possibly due to a decline in use of high GV sires. Sires from Canada constituted $9 \%$ of the total, and these 
de cambios de los promedios de VG en el PNMG fueron similares con los de la población AHM que los de la población BNIL, especialmente los promedios de las vacas y los ponderados de los toros.

Los promedios no ponderados de los VG de los sementales por año de parto en el PNMG, la AHM, y el BNIL (Figura 5) muestran claramente que, excepto por el año 2007 (muestreo no representativo en el BNIL), el valor genético promedio de los toros en la AHM fue superior al de los toros en el PNMG y el BNIL, similar a lo que se presentó para los valores genéticos de las vacas. Sin embargo, lo opuesto ocurrió con los promedios ponderados de toros (Figura 6): Ios del BNIL fueron superiores a aquéllos de la AHM y del PNMG. Esto sugiere que los ganaderos pertenecientes al BNIL a pesar de escoger toros con valores genéticos variados, usan con mayor frecuencia los de los valores had weighted average GV lower than those of USA and Others sires but higher than Mexico sires. However, the Canada sires' averages tended to increase linearly up to 2010 and decreased slightly in 2011. This indicates continual use of high GV Canadian sires. Representing $8 \%$ of the total, the sires from Mexico had the lowest GV of the four categories; these increased up to 2009 and then decreased in 2010 and 2011. This GV pattern among country categories probably reflects longer histories of genetic improvement selection programs, and larger populations of registered Holstein dairy cattle in the USA, Others and Canada categories. These results coincide with a previous study using records for only 48 herds which compared sire GV among the USA, Canada and Mexico, in which GV were higher in USA sires, followed by those from Canada and Mexico(15). Another study also found that sires from abroad had higher average GV than Mexican sires(13).

Figura 5. Tendencias genéticas de producción de leche a 305 días para los sementales por año de parto de sus hijas (medias no ponderadas), para el Programa Nacional de Mejoramiento Genético (PNMG); la Asociación Holstein de México (AHM) y el Banco Nacional de Información Lechera (BNIL)

Figure 5. Sire 305-d milk production genetic tendencies (unweight means) by daughter year of birth from data in the National Genetic Improvement Program (PNMG), the Holstein Association of Mexico (AHM) and the National Dairy Data Bank (BNIL)

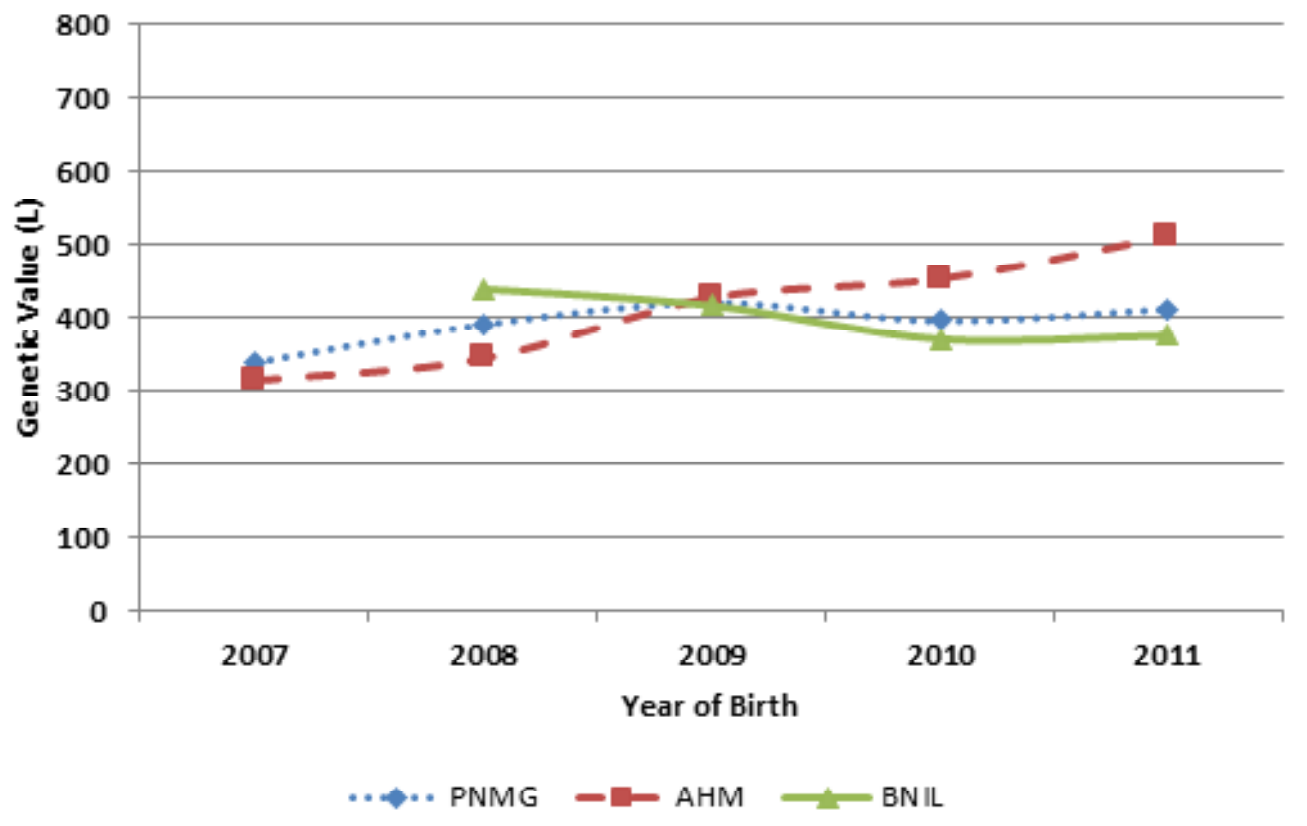


más altos; no obstante, los ganaderos de la AHM seleccionan toros con valores genéticos altos de forma homogénea, lo que permite que los promedios de valores genéticos tanto de sementales como vacas tengan valores genéticos superiores a los del BNIL. Las tendencias genéticas de las medias no ponderadas de los sementales y de las vacas para producción de leche en este trabajo concuerdan con otros estudios realizados en México que han reportado que los VG promedio de los sementales y de las vacas en producción en hatos en México incrementó durante el periodo de estos estudios(2,12-15). Esto se debe probablemente a un efecto combinado de inmigración de material genético (principalmente semen de EUA) y de selección de padres en los programas de mejoramiento genético en México.
Phenotypic tendencies

Dairy cow annual average PhV adjusted for first lactation in the PNMG, AHM and BNIL data exhibited behavior similar to average GV for each of these populations (Figure 1). Average cow PhV were double those of cow GV. Cow average GV and PhV in the AHM data (excluding 2007) were higher than in the BNI L data in 2008, 2009 and 2010, but equal to them in 2011. This suggests that average cow mother quality was lower in the BNIL cows than in the AHM cows. These data are apparently similar to the positive tendencies reported in a study of unweighted and weighted genetic and phenotypic values for cows and sires in Mexican herds from 1977 to 1983 using a smaller number of herds and records than in the present study.

Figura 6. Tendencias genéticas de producción de leche a 305 días para los sementales por año de parto de sus hijas (medias ponderadas), para el Programa Nacional de Mejoramiento Genético (PNMG); la Asociación Holstein de México (AHM) y el Banco Nacional de Información Lechera (BNIL)

Figure 6. Sire 305-dy milk production genetic tendencies (weighted means) by daughter year of birth from data in the National Genetic Improvement Program (PNMG), the Holstein Association of Mexico (AHM) and the National Dairy Data Bank (BNIL)

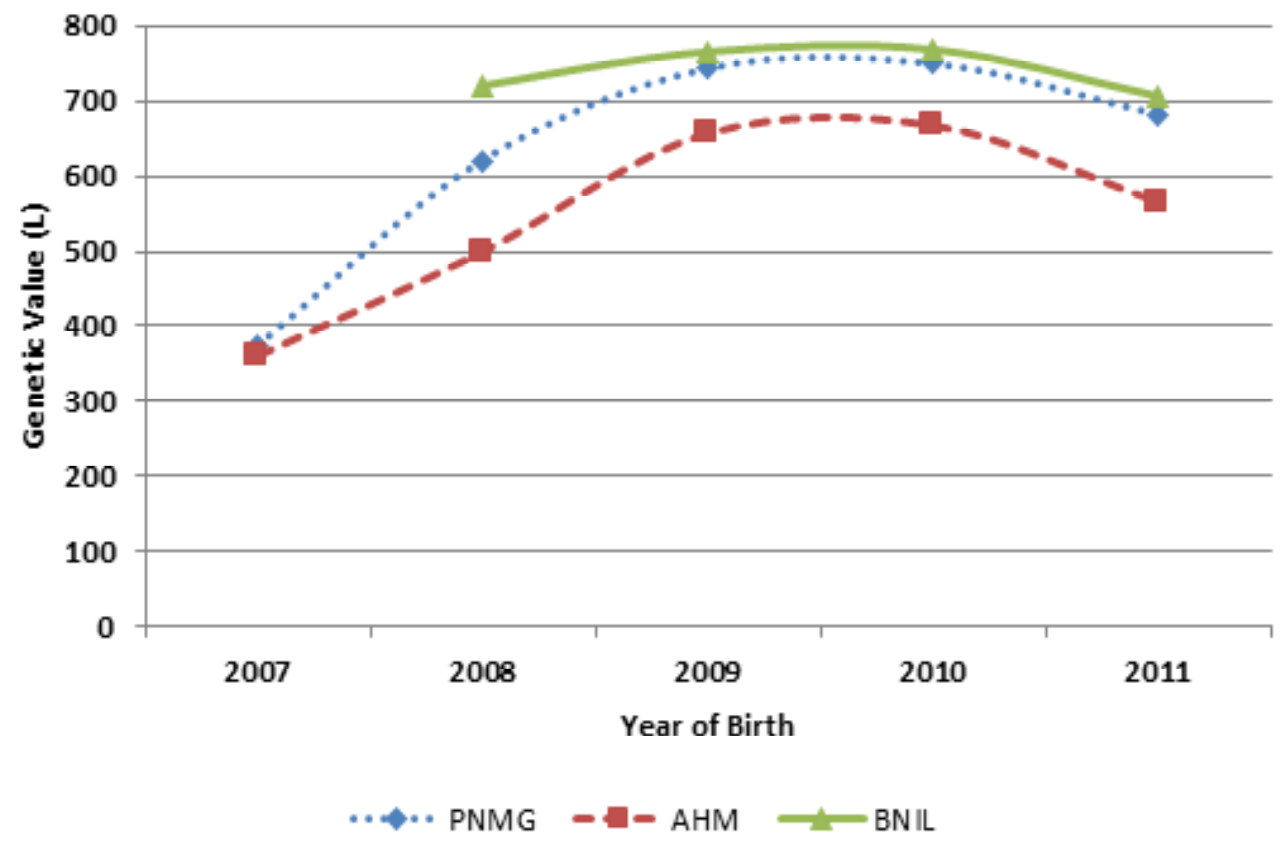


Las tendencias genéticas de producción de leche a 305 días por año de parto para los sementales del PNMG de acuerdo a su país de origen se presentan en la Figura 7. Estos promedios ponderados reflejan el grado de utilización de los sementales de las categorías de países definidas aquí. Las medias ponderadas de los VG fueron más altas para los sementales de EUA que para el resto de los países. Estas aumentaron hasta el año 2010 y decrecieron levemente en el año 2011. Este comportamiento fue similar al observado para los promedios de VG ponderados del PNMG que incluyeron VG de los sementales de todos los países (Figura 6). Esto probablemente se debió a que los sementales de EUA representaron el $70 \%$ del total de sementales usados en el PNMG. La categoría Otros (Alemania, Australia, Austria, España, Francia, Gran Bretaña, Holanda, Italia,
Use of high genetic value sires constantly increased during the study period, leading to higher genetic and phenotypic values in dairy cows in Mexico. Sires from outside Mexico had higher genetic values than those from Mexico and were used more frequently by producers during the study period. If this trend in importing large amounts of sperm from the USA and other countries continues, genetic tendencies in dairy production in Mexico will continue to be heavily influenced by this genetic material, although selection of domestic sires and cows will also have a substantial effect.

\section{ACKNOWLEDGMENTS}

This research was supported by the Consejo Nacional de los Recursos Genéticos Pecuarios

Figura 7. Tendencias genéticas de producción de leche a 305 días para los sementales por año de parto de sus hijas (medias ponderadas), del Programa Nacional de Mejoramiento Genético (PNMG) con origen de Canadá, México, EUA, y Otros

Figure 7. Sire 305-d milk production genetic tendencies (weighted means) by daughter year of birth from data in the National Genetic Improvement Program (PNMG) for sires from Canada, Mexico, the United States (USA) and Others

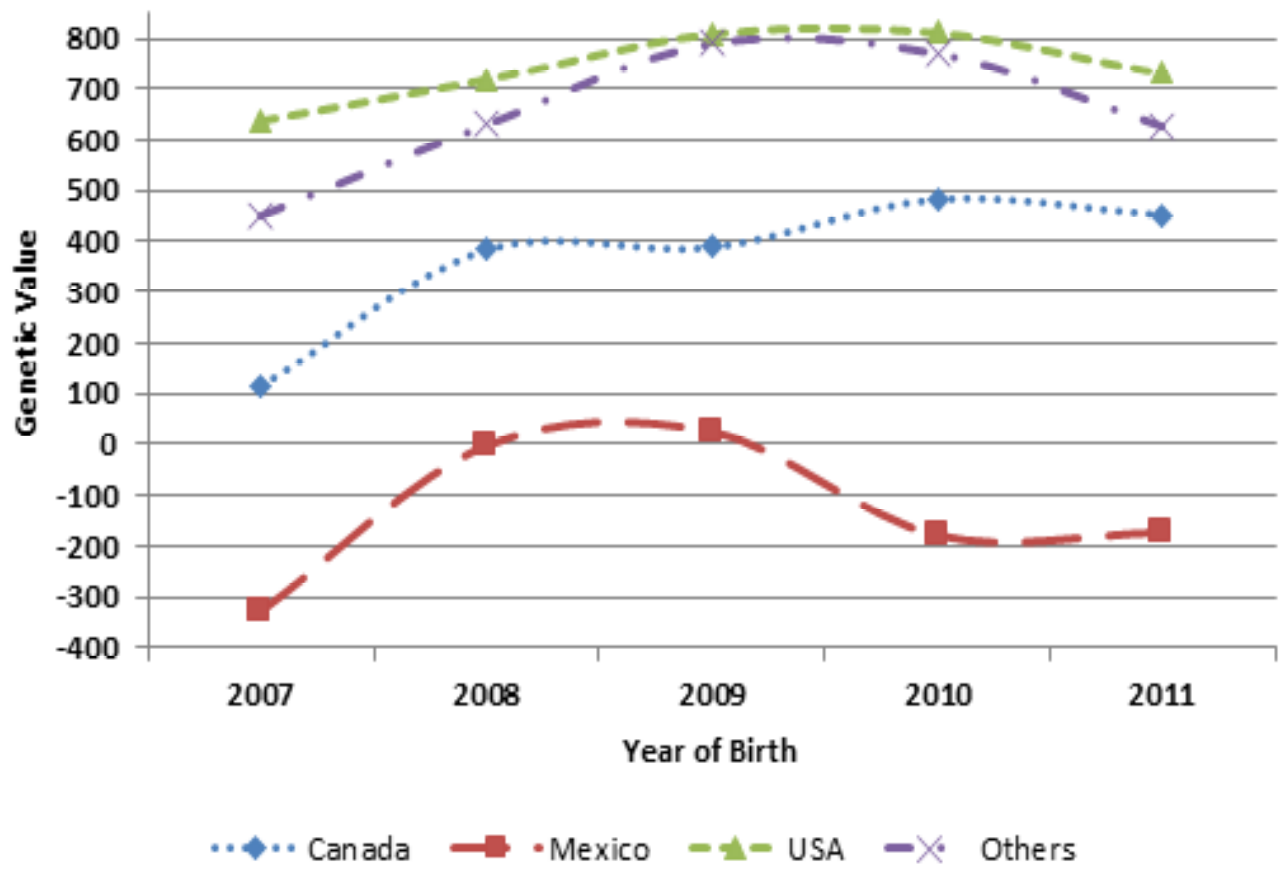


Nueva Zelandia, Republica Checa, y Suecia) tuvo promedios ponderados de VG inferiores a los de EUA, pero superiores a los de Canadá y de México. Los países incluidos en la categoría Otros representaron el $13 \%$ del total. Los promedios ponderados de Otros se incrementaron hasta el año 2009 y después disminuyeron en los años 2010 y 2011 sugiriendo una disminución en el uso de los sementales con altos VG. Los sementales de Canadá constituyeron el $9 \%$ del total. Los promedios ponderados de VG de los sementales de Canadá fueron inferiores a los de EUA y Otros, pero superiores a los de México. Estos promedios ponderados de sementales canadienses tendieron a incrementar linealmente hasta el año 2010 y en el año 2011 disminuyeron ligeramente. Esto indica un uso continuo de sementales canadienses con altos VG. Por último los valores genéticos de los sementales mexicanos aumentaron hasta el año 2009 y disminuyeron en el año 2010 y 2011. Los VG de los sementales mexicanos fueron inferiores a los de EUA, Canadá y Otros y representaron el $8 \%$ del total. Los valores superiores de VG probablemente se debieron a que los países como EUA, Canadá y Otros tienen mayor tiempo de selección y poblaciones con registros de producción de leche en ganado Holstein de mayor tamaño. Estos resultados concordaron con una comparación entre valores genéticos de sementales de EUA, Canadá y México(15) utilizando un número menor de registros provenientes de 48 hatos. McDowell et al(15) encontraron un mayor VG para los sementales de EUA seguidos por los de Canadá, y después por los sementales mexicanos. Valencia et al(13) también hallaron que los sementales extranjeros tuvieron VG superiores en promedio a los sementales mexicanos.

\section{Tendencias fenotípicas}

Los promedios anuales de los VF de las vacas de producción de leche ajustada de la primera lactancia en el PNMG, la AHM, y el BNIL tuvieron un comportamiento similar a los promedios de los VG (Figura 1) de estas poblaciones. Excepto que los promedios de los VF fueron el doble de and the Asociación Holstein de México through access to their databases. The first author received a Master's scholarship from the CONACyT in support of this research.

End of english version

los VG de las vacas. Los promedios genéticos y fenotípicos de las vacas de la AHM (ignorando el 2007 debido a la falta de representatividad de la muestra del BNIL) fueron superiores a los del BNIL en los años 2008, 2009, y 2010, y prácticamente iguales en el 2011. Esto indica que la calidad promedio de las madres de las vacas en el BNIL fue aparentemente menor al de las vacas de la AHM. También, Rosales y Tewolde(2) estimaron tendencias genéticas y fenotípicas positivas no ponderadas para vacas y sementales en hatos mexicanos (menor número de hatos y de registros que en este estudio) entre los años 1977 y 1983.

El incremento de utilización de sementales con altos valores genéticos por parte de los ganaderos durante los años del estudio ha sido constante. El mayor uso que se le ha dado a los sementales con valores genéticos superiores ha permitido el incremento de los valores genéticos y fenotípicos de las vacas en producción en México. Los sementales extranjeros tuvieron VG superiores a los nacionales y fueron más utilizados por los ganaderos durante los años analizados en este trabajo. Si los ganaderos continúan importando cantidades de semen importantes de EUA y otros países, las tendencias genéticas para producción de leche en México continuaran siendo influenciadas tanto por importación de material genético como de selección interna de sementales y de vacas.

\section{AGRADECIMIENTOS}

Se agradece al Consejo Nacional de los Recursos Genéticos Pecuarios y a la Asociación Holstein 
de México, por el apoyo en la realización de este proyecto al facilitar las bases de datos. Así como al CONACyT por otorgar una beca de maestría al primer autor para realizar este estudio.

\section{LITERATURA CITADA}

1. Villamar AL, Olivera CE. Situación actual y perspectiva de la producción de leche de bovino en México 2005. Coordinación General de Ganadería. SAGARPA. 2005, México.

2. Rosales AJ, Tewolde MA. Estimación del progreso genético en hatos de bovinos en Holstein mexicanos. Vet Mex 1993;24 (3): 185-188.

3. Toledo AH, Ruiz LF, Vásquez PC, Berruecos VJ, Elzo A. Parámetros genéticos para producción de leche de ganado Holstein en dos modalidades de control de producción. Rev Mex Cienc Pecu 2014;5(4):443-457.

4. Microsoft. C\# Programming Guide, Visual C\#, MSDN. Microsoft Corp. USA. 2012.

5. SAS. Institute, Inc. SAS/STAT Users Guide, version 9.2 ed. Cary, North Carolina, USA: SAS Institute Inc., 1997.

6. Asociación Holstein de México. Resumen ejecutivo, Programa Nacional de Mejoramiento Genético de Bovinos Productores de Leche. SAGARPA, CONARGEN, Santiago de Querétaro, México 2010.

7. García E. Modificaciones al sistema de clasificación climática de Köpen para adaptarlo a las condiciones de la República Mexicana. Instituto de Geografía. UNAM. México DF, 2004.

8. Améndola $R$, Castillo $E$, Arturo $P$, Perfiles por país del recurso pastura / forraje. FAO. 2005.

9. Gilmour AR, Thompson R, Cullis RR. AIREML, an efficient algorithm for variance parameter estimation in linear mixed models. Biometrics 1995;51:1440-1450.

10. Gilmour AR, Gogel BJ, Cullis BR, Thompson R. ASReml User Guide Release 3.0 VSN International LTD, UK, 2009.

11. Henderson CR. Application for linear models in animal breeding. Canadá, University of Guelph, 1984.

12. Palacios EA, Rodríguez $A F$, Jiménez $C J$, Espinoza VJ, Núñez DR. Evaluación genética de un hato Holstein en baja california sur, utilizando un modelo animal con mediciones repetidas. Ensayo. Agrociencia 2001;35:347-353.

13. Valencia PM, Ruíz LF, Montaldo VH, Keown JF, Van Vleck LD. Evaluación genética para la producción de leche en ganado Holstein en México. Téc Pecu Méx 1999;37(3):1-8.

14. Powell RL, Wiggans GR. Animal model evaluations for Mexican Holsteins. J Dairy Sci 1991;74:1420-1427.

15. McDowell RE, Wiggans GR, Camoens JK, Van Vleck LD, ST.Luis DG. Sire comparisons for Holsteins in Mexico versus the United States and Canada. J Dairy Sci 1976;59(2):298304. 
